\title{
Genome-wide 5-hydroxymethylcytosine patterns in human spermatogenesis are associated with semen quality
}

\author{
Olga A. Efimova ${ }^{1,2, *}$, Anna A. Pendina ${ }^{1,2,3, *}$, Andrei V. Tikhonov ${ }^{1,2,3, *}$, Sergey E. \\ Parfenyev $^{2}$, Irina D. Mekina ${ }^{1}$, Evgeniia M. Komarova ${ }^{1}$, Mariia A. Mazilina ${ }^{1,2}$, Eugene \\ V. Daev², Olga G. Chiryaeva ${ }^{1,4,5}$, Ilona A. Galembo ${ }^{3}$, Mikhail I. Krapivin ${ }^{2}$, Oleg S. \\ Glotov $^{1,2}$, Irina S. Stepanova ${ }^{6,7}$, Svetlana A. Shlykova ${ }^{8}$, Igor Yu. Kogan ${ }^{1}$, Alexander \\ M. Gzgzyan ${ }^{1,2}$, Tatyana V. Kuznetzova ${ }^{1,2}$ and Vladislav S. Baranov ${ }^{1,2}$ \\ ${ }^{1}$ D.O. Ott Research Institute of Obstetrics, Gynecology and Reproductology, St. Petersburg, Russia \\ 2 St. Petersburg State University, St. Petersburg, Russia \\ ${ }^{3}$ Center for Medical Genetics, St. Petersburg, Russia \\ ${ }^{4}$ St. Petersburg State Pediatric Medical University, St. Petersburg, Russia \\ ${ }^{5}$ S.M. Kirov Military Medical Academy, St. Petersburg, Russia \\ ${ }^{6}$ Institute of Cytology RAS, St. Petersburg, Russia \\ ${ }^{7}$ Aimed Clinic, St. Petersburg, Russia \\ ${ }^{8}$ AVA-Peter Clinic, St. Petersburg, Russia \\ * These authors have contributed equally to this work \\ Correspondence to: Olga A. Efimova, email: efimova_082@mail.ru \\ Keywords: 5-hydroxymethylcytosine, semen quality, sperm DNA fragmentation, human spermatogenesis, testicular spermatogen- \\ ic cells, Pathology Section \\ Received: August 01, $2016 \quad$ Accepted: May 21, $2017 \quad$ Published: June 01, 2017
}

Copyright: Efimova et al. This is an open-access article distributed under the terms of the Creative Commons Attribution License 3.0 (CC BY 3.0), which permits unrestricted use, distribution, and reproduction in any medium, provided the original author and source are credited.

\section{ABSTRACT}

We performed immunofluorescent analysis of DNA hydroxymethylation and methylation in human testicular spermatogenic cells from azoospermic patients and ejaculated spermatozoa from sperm donors and patients from infertile couples. In contrast to methylation which was present throughout spermatogenesis, hydroxymethylation was either high or almost undetectable in both spermatogenic cells and ejaculated spermatozoa. On testicular cytogenetic preparations, 5-hydroxymethylcytosine was undetectable in mitotic and meiotic chromosomes, and was present exclusively in interphase spermatogonia Ad and in a minor spermatid population. The proportions of hydroxymethylated and non-hydroxymethylated diploid and haploid nuclei were similar among samples, suggesting that the observed alterations of 5-hydroxymethylcytosine patterns in differentiating spermatogenic cells are programmed. In ejaculates, a few spermatozoa had high 5-hydroxymethylcytosine level, while in the other ones hydroxymethylation was almost undetectable. The percentage of highly hydroxymethylated (5-hydroxymethylcytosine-positive) spermatozoa varied strongly among individuals. In patients from infertile couples, it was higher than in sperm donors $(P<0.0001)$ and varied in a wider range: $0.12-21.24 \%$ versus $0.02-0.46 \%$. The percentage of highly hydroxymethylated spermatozoa correlated strongly negatively with the indicators of good semen quality - normal morphology $(r=-0.567, P<0.0001)$ and normal head morphology $(r=-0.609$, $P<0.0001)$ - and strongly positively with the indicator of poor semen quality: sperm DNA fragmentation $(r=0.46, P=0.001)$. Thus, the immunocytochemically detected increase of $5 \mathrm{hmC}$ in individual spermatozoa is associated with infertility in a couple and with deterioration of sperm parameters. We hypothesize that this increase is not programmed, but represents an induced abnormality and, therefore, it can be potentially used as a novel indicator of semen quality. 


\section{INTRODUCTION}

Human spermatozoa have a unique epigenome which is formed through epigenetic changes during a long period of differentiation from primordial germ cells to mature gametes. The establishment of appropriate epigenetic patterns through DNA demethylation/ remethylation, chromatin remodeling and non-coding RNAs is integral to achieving high spermatozoon specialization, which is required for the transmission of genetic and epigenetic information and initiation of embryo development [1].

A major mechanism of human genome reprogramming is DNA methylation [2-4]. Establishment, maintenance and alteration of specific 5-methylcytosine $(5 \mathrm{mC})$ patterns are the key aspects in cell fate determination through arrangement of DNA-protein interactions and activation / repression of specific gene expression programs [5]. Errors in these processes are associated with various human pathologies [6-10]. Along with $5 \mathrm{mC}$, the DNA methylation/demethylation cycle includes three other forms of modified cytosine: 5-hydroxymethylcytosine $(5 \mathrm{hmC}), 5$-formylcytosine and 5-carboxylcytosine. They are produced by ten eleven translocation (TET)-mediated $5 \mathrm{mC}$ oxidation as intermediate products in active DNA demethylation [11, 12]. However, many current studies discuss the epigenetic effect of $5 \mathrm{mC}$ oxidative derivatives, especially of $5 \mathrm{hmC}$, in genome function regulation [13-15].

DNA methylation patterns in mature spermatozoa are rather well studied [16-18]. The sperm methylome differs markedly from that of somatic cells, but is similar to that in embryonic stem cells and embryonic germ cells [16]. The establishment of germ-cell-specific DNA methylation signatures is a highly determined process. However, the reversibility of cytosine modification mechanisms provides methylome plasticity, which is believed to be important for adaptation to environmental factors through alterations of genome activity $[19,20]$. In human, the development of germ cells from spermatogonia to spermatozoa takes 74 days [21,22] and is accompanied by a decrease in the amount of cytoplasm which makes both genetic and epigenetic patterns in spermatogenic cells and mature spermatozoa highly vulnerable to internal and external factors [23]. Aberrant DNA methylation changes in sperm have been shown to increase risk of reproductive failures [24], and to deregulate gene expression and promote genome instability [25, 26]. Moreover, specific alterations of germline DNA methylation are associated with variation in sperm morphology and motility [27-29].

Considering that DNA methylation may be changed through $5 \mathrm{mC}$ hydroxylation and that the $5 \mathrm{hmC}$ itself has a regulatory role in gene expression, it is of both fundamental and practical importance to study DNA hydroxymethylation patterns in human spermatogenesis.
To date, sperm hydroxymethylation patterns have been reported only in few studies, which have quantified $5 \mathrm{hmC}$ in DNA from multi-cell samples: absolute level in the whole ejaculate $[30,31]$ and gene-specific hydroxymethylation levels in the populations of normal, abnormal and globozoospermic spermatozoa [32]. However, the analysis of genomic DNA extracted from multi-cell samples shows an average hydroxymethylation level leaving the possibility that a simultaneous increase of $5 \mathrm{hmC}$ level in some cells and a decrease in others remains undetected.

In this study, we analyze genome-wide $5 \mathrm{hmC}$ and $5 \mathrm{mC}$ patterns in human testicular spermatogenic cells and ejaculated spermatozoa, using immunocytochemical detection in situ. This technique allows single-cell analysis of large cell populations in each individual and, importantly, allows revealing the discreteness of germ cell epigenetic marking. We address the following questions concerning $5 \mathrm{hmC}$ patterns in normal and pathological human spermatogenesis: 1) whether sperm $5 \mathrm{hmC}$ patterns show inter-cell and inter-individual variation in sperm donors versus patients from infertile couples; 2) whether sperm $5 \mathrm{hmC}$ patterns are associated with semen parameters; and 3) whether $5 \mathrm{hmC}$ patterns undergo global changes during differentiation of spermatogenic cells.

\section{RESULTS}

\section{Sperm 5-hydroxymethylcytosine and 5-methylcytosine patterns}

Using the immunofluorescent approach, we evaluated the presence of $5 \mathrm{hmC}$ and $5 \mathrm{mC}$ in human ejaculated spermatozoa fixed on glass slides. Intercellular variability in anti-5hmC fluorescence intensity was strongly pronounced: $5 \mathrm{hmC}$ was almost completely absent in most spermatozoa and only a few of them had high hydroxymethylation level (Figure 1). The frequency of highly hydroxymethylated (5hmC-positive) spermatozoa in the patients from infertile couples was significantly higher than that in the sperm donors: 0.12 $21.24 \%$ versus $0.02-0.46 \%(P<0.0001)$ (Figure 2$)$. The range of deviation in patients was 48 fold higher than in sperm donors.

In contrast to $5 \mathrm{hmC}, 5 \mathrm{mC}$ was present in all spermatozoa to an easily detectable level (Figure 1). Intercellular variability in anti- $5 \mathrm{mC}$ fluorescence intensity was not obviously visible by the qualitative analysis. However, the quantitative analysis of anti-5mC fluorescence intensity showed a higher methylation level in $5 \mathrm{hmC}$ positive spermatozoa $(P<0.0001)$ (Figure 3 ). 


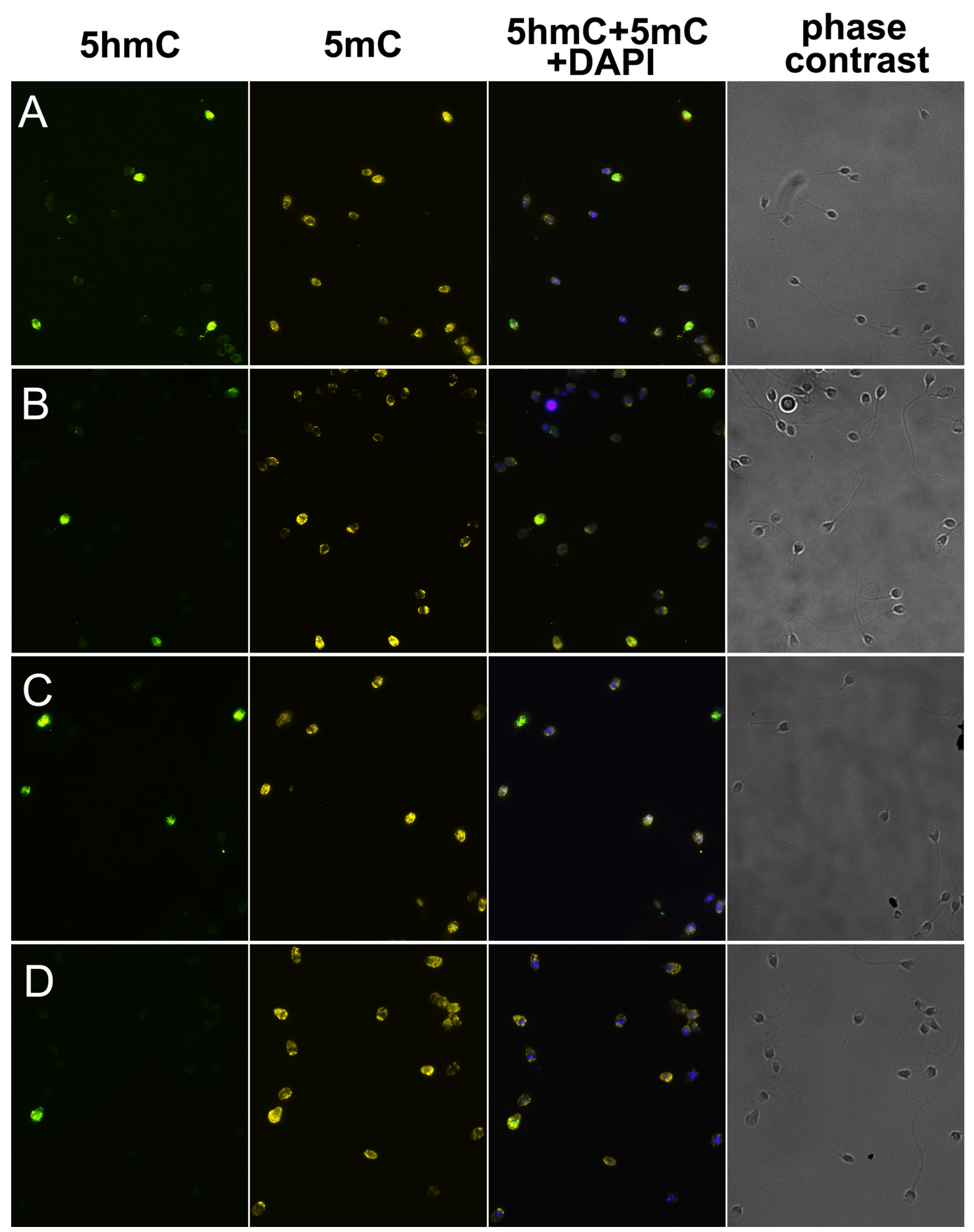

Figure 1: 5-hydroxymethylcytosine $(5 \mathrm{hmC})$ and 5-methylcytosine $(5 \mathrm{mC})$ patterns in human ejaculated spermatozoa. Immunostaining for $5 \mathrm{hmC}, 5 \mathrm{mC}$, merge image, and phase-contrast images of spermatozoa from patients (A-C) and a sperm donor (D), having $10.04 \%, 6.04 \%, 21.24 \%$, and $0.46 \%$ of $5 \mathrm{hmC}$-positive spermatozoa in ejaculate, respectively. 
Table 1: Semen parameters of analyzed sperm donors and patients from infertile couples.

\begin{tabular}{|l|c|c|c|}
\hline Semen parameters & Sperm donors, $\boldsymbol{n}=\mathbf{1 3}$ & Patients from infertile couples, $\boldsymbol{n}=\mathbf{3 7}$ & $\boldsymbol{P}$-values \\
\hline Concentration $\left(\times 10^{6} / \mathrm{ml}\right)$ & $118.3(64-191)$ & $128.1(2-340)$ & 0.9434 \\
\hline Total motility (\%) & $86.15(65-100)$ & $87.92(47-100)$ & 0.5623 \\
\hline Progressive motility (\%) & $68.85(49-90)$ & $57(17-88)$ & $0.0487^{*}$ \\
\hline Non-progressive motility (\%) & $17.31(3-38)$ & $30.92(1-83)$ & 0.1472 \\
\hline Normal morphology (\%) & $12.69(6-24)$ & $5.946(0-22)$ & $0.0003^{*}$ \\
\hline Normal head (\%) & $13.62(5-24)$ & $4.235(0-25)$ & $<0.0001^{*}$ \\
\hline Abnormal morphology (\%) & $67.00(28-94)$ & $90.68(73-100)$ & $<0.0001^{*}$ \\
\hline Abnormal head (\%) & $74.08(52-92)$ & $85.97(68-100)$ & $0.0008^{*}$ \\
\hline Abnormal tail (\%) & $1.54(0-10)$ & $1.24(0-11)$ & 0.3751 \\
\hline Abnormal midpiece (\%) & $5.54(0-22)$ & $3.46(0-12)$ & 0.62 \\
\hline
\end{tabular}

Semen parameters are shown as mean and range (minimum to maximum). $P$-values were calculated using the Mann-Whitney U-test. $P$-values showing statistically significant difference between the groups are marked by *.

\section{Sperm 5-hydroxymethylcytosine pattern in relation to semen parameters}

Using correlation analysis, we checked the strength and the direction of relationship between the highly hydroxymethylated spermatozoa percentage and other sperm parameters in 50 individuals analyzed in this study. The sperm parameters included sperm DNA integrity, assessed by terminal deoxynucleotidyl transferasemediated dUTP nick-end labelling (TUNEL) on glass slides, and standard quantitative and qualitative sperm characteristics: concentration, motility and morphology, including normal head, abnormal head, abnormal tail, and abnormal midpiece.

The percentage of highly hydroxymethylated spermatozoa showed a strong positive correlation with the frequency of TUNEL-positive spermatozoa $(r=$ $0.46, P=0.001)$ and a strong negative correlation with the frequency of morphologically normal $(r=-0.567$, $P<0.0001)$ and normal-head spermatozoa $(r=-0.609$, $P<0.0001)$. A weak positive correlation was observed with non-progressive motility $(r=0.346, P=0.014)$ and with total motility $(r=0.317, P=0.025)$. No statistically significant correlations were found between the percentage of highly hydroxymethylated spermatozoa and other parameters, including concentration $(r=0.077, P=0.595)$, progressive motility $(r=-0.192, P=0.183)$, abnormal-tail spermatozoa $(r=0.142, P=0.327)$, or abnormal midpiece $(r=-0.157, P=0.276)$ (Figure 4).

Thus, the frequency of highly hydroxymethylated spermatozoa in ejaculate is associated with a variation in sperm parameters, showing strong negative correlation with indicators of good semen quality - the frequency of morphologically normal and normal-head spermatozoa, and strong positive correlation with the indicator of poor semen quality - the frequency of TUNEL-positive spermatozoa.

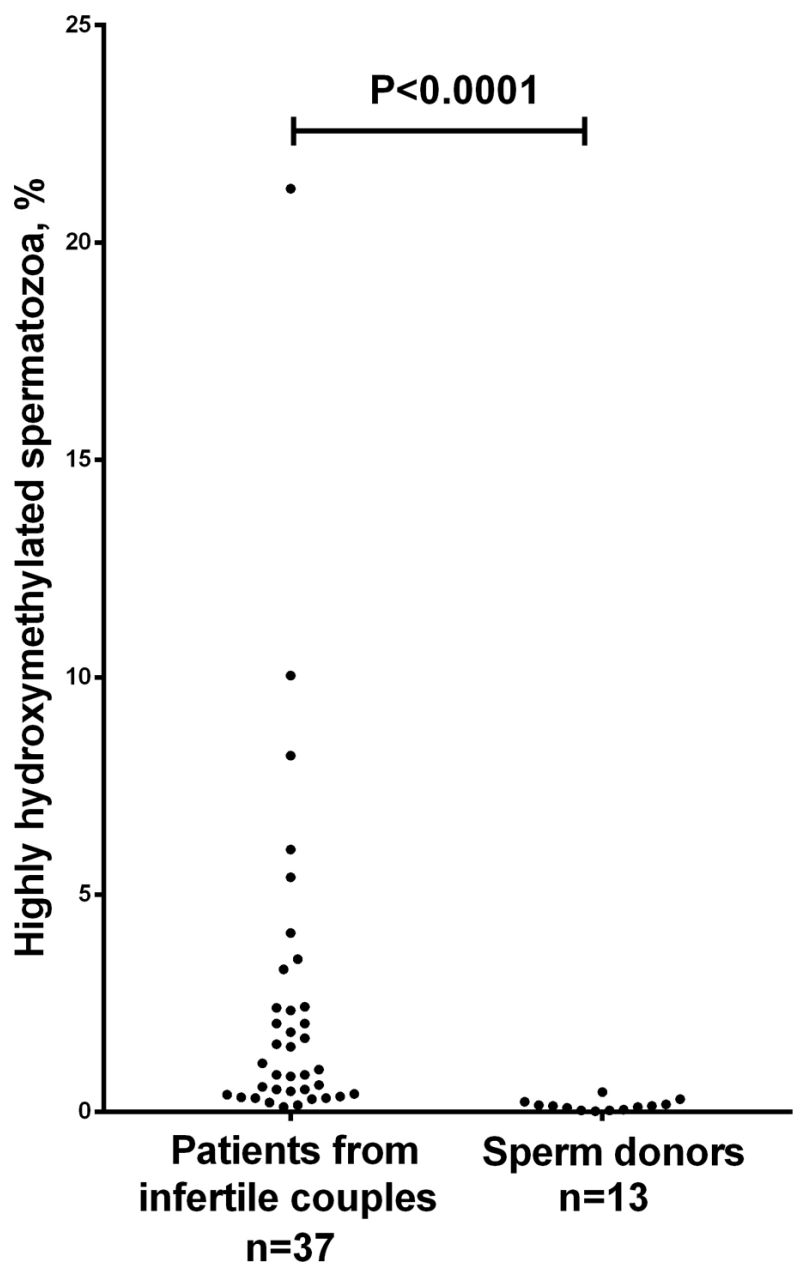

Figure 2: Scatter dot plot showing the percentage of immunocytochemically detected highly hydroxymethylated (5hmC-positive) spermatozoa in ejaculates from sperm donors versus patients from infertile couples. ${ }^{*}$ The frequency of $5 \mathrm{hmC}$-positive spermatozoa is significantly higher in patients compared to sperm donors $(P<0.0001$, the Mann-Whitney U-test). All $5 \mathrm{hmC}$-positive spermatozoa had visible anti-5-methylcytosine fluorescence. 


\section{DNA hydroxymethylation and methylation patterns in spermatogenic cells}

We have studied DNA hydroxymethylation and methylation patterns in human spermatogenic cells from testicular tissue samples of azoospermic patients. We performed simultaneous immunodetection of $5 \mathrm{hmC}$ and
$5 \mathrm{mC}$ on testicular cytogenetic preparations - chromosomes and nuclei fixed on glass slides and stained with quinacrine-fluorescence-Hoechst (QFH). We identified spermatogonial mitotic chromosomes at metaphase stage and spermatocyte meiotic chromosomes at prophase I (pachytene, diplotene, and diakinesis) and metaphase II stages.

When analyzing DNA methylation pattern, we
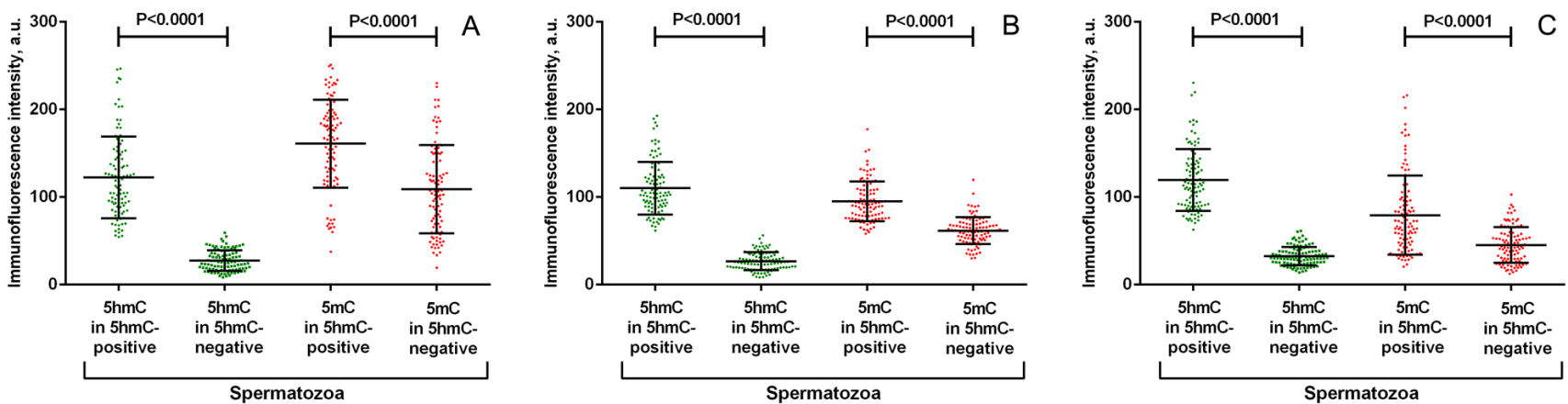

Figure 3: Quantitative analysis of anti-5-hydroxymethylcytosine $(5 \mathrm{hmC})$ and anti-5-methylcytosine $(5 \mathrm{mC})$ fluorescence intensity in representative spermatozoa from 3 individuals $(\mathbf{A}, \mathbf{B}, \mathbf{C}) . *$ Both anti-5hmC and anti-5mC fluorescence intensities differ significantly between 5hmC-positive and 5-hmC-negative spermatozoa $(P<0.0001$, the Mann-Whitney U-test).
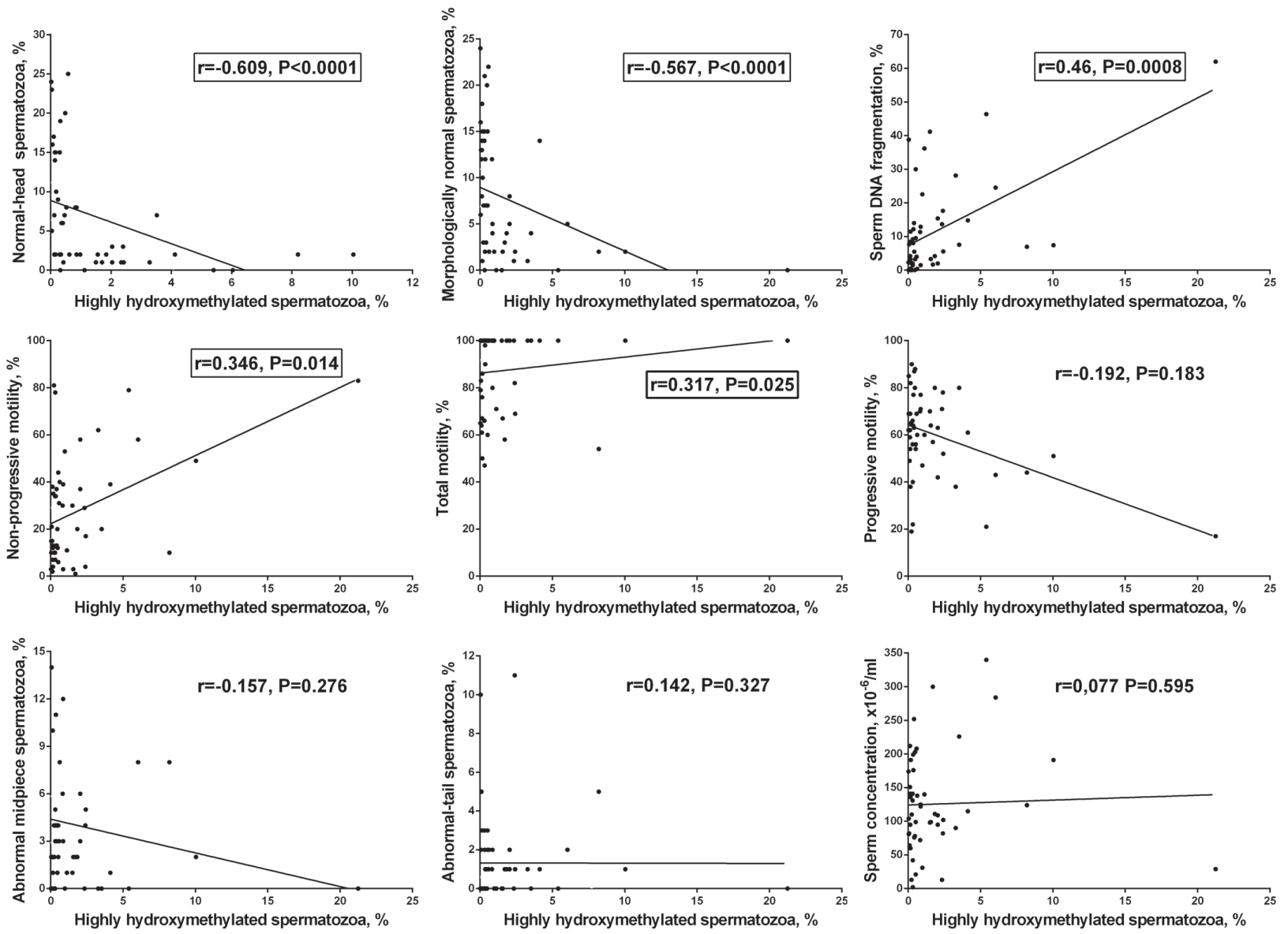

Figure 4: Correlations between the frequency of highly hydroxymethylated (5hmC-positive) spermatozoa in human ejaculate and semen parameters. Statistically significant correlations are framed $(P<0.05$, the nonparametric Spearman test). 
detected $5 \mathrm{mC}$ in all nuclei and in both mitotic and meiotic chromosomes (Figure 5). There was no obvious internuclei difference in DNA methylation intensity. The distribution of $5 \mathrm{mC}$ along the arms of spermatogonial mitotic chromosomes was band-specific. The $5 \mathrm{mC}$-richest chromosome regions corresponded to QFH-negative euchromatic bands (R-bands), whereas QFH-positive euchromatic bands (G-bands) were methylated to a lesser extent (Figure 5).

A specific $5 \mathrm{mC}$ distribution pattern was also detected in the meiotic chromosomes. In the pachytene chromosomes, $5 \mathrm{mC}$ was present in interchromomeric segments with a higher methylation level in near-telomeric regions. Similarly, in the diplotene, diakinetic, and metaphase II chromosomes, methylation was present nonrandomly along arms (Figure 5).

When examining $5 \mathrm{hmC}$ distribution in the chromosomes and nuclei on the same preparations, we revealed a remarkably different pattern from that of $5 \mathrm{mC}$.
$5 \mathrm{hmC}$ level was extremely low/undetectable in both mitotic and meiotic chromosomes, including prophase I (pachytene, diplotene, and diakinesis) and metaphase II stages (Figure 5). Hydroxymethylation in interphase nuclei was present either at high or at extremely low/ undetectable level (Figure 6A).

We determined whether the nuclei were from premeiotic/somatic or postmeiotic cells based on their ploidy, revealed by fluorescence in situ hybridization (FISH) prior to the immunodetection of $5 \mathrm{hmC}$. Four types of nuclei were detected: hydroxymethylated diploid, nonhydroxymethylated diploid, hydroxymethylated haploid, and non-hydroxymethylated haploid nuclei (Figure 6A). The proportions of nucleus types did not differ between patients with obstructive and non-obstructive azoospermia $(P=0.978)$, suggesting that stages of spermatogenesis were similarly represented in all the analyzed individuals (Figure 6B). The percentage of hydroxymethylated nuclei among diploid ones varied from 32.62 to 52.57

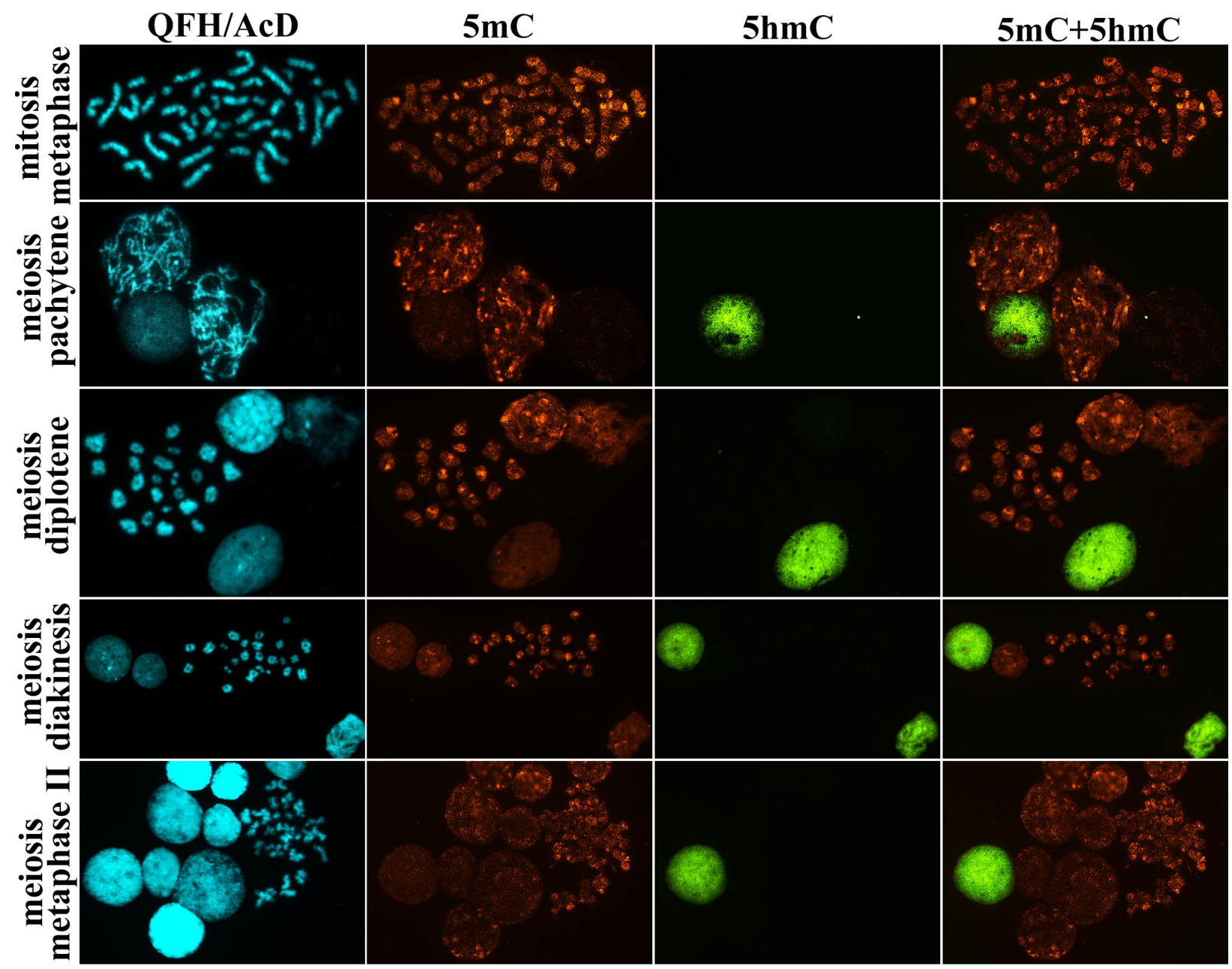

Figure 5: 5-hydroxymethylcytosine $(5 \mathrm{hmC})$ and 5-methylcytosine $(5 \mathrm{mC})$ patterns in human testicular cells: mitotic spermatogonium at metaphase stage, meiotic spermatocytes at prophase (pachytene, diplotene and diakinesis) stage and metaphase II stage after QFH/AcD banding and immunodetection of $\mathbf{5 h m C}$ and $\mathbf{5 m C}$. In both mitotic and meiotic chromosomes from spermatogenic cells $5 \mathrm{hmC}$ is undetectable, whereas $5 \mathrm{mC}$ is present. QFH/AcD staining and photoimaging of banded chromosomes were performed before the $5 \mathrm{hmC}$ and $5 \mathrm{mC}$ immunodetection. 
$\%$ in different samples (mean 40.75 \pm 5.89 ). Among hydroxymethylated diploid nuclei, we observed the prevalence of nuclei with a large vacuole - a specific characteristic of Ad, but not Ap or B spermatogonia [33]. The diploid hydroxymethylated nuclei with no vacuole, which might be either from somatic or from spermatogenic cells, amounted to no more than 1-2\%. The percentage of hydroxymethylated nuclei among haploid ones varied from 0.42 to $1.96 \%$ in different samples (mean $1.18 \pm 0.51$ ).

On the testicular cytogenetic preparations from 13 out of 15 patients, we detected a total of 283 spermatozoa with no highly hydroxymethylated ones. All the analyzed spermatozoa had basically low $5 \mathrm{hmC}$ level.

We then performed immunohistochemical staining of testis tissue sections detecting $5 \mathrm{hmC}$ and $5 \mathrm{mC}$. In accordance with our results on cytogenetic preparations, $5 \mathrm{mC}$ was present in all cell types within the tubules, while $5 \mathrm{hmC}$ was visible only in some cells. The hydroxymethylated cells mostly located near the basal membrane and had vacuoles (Figure 7). Thus, in contrast to $5 \mathrm{mC}$, which is present in all testicular cells, $5 \mathrm{hmC}$
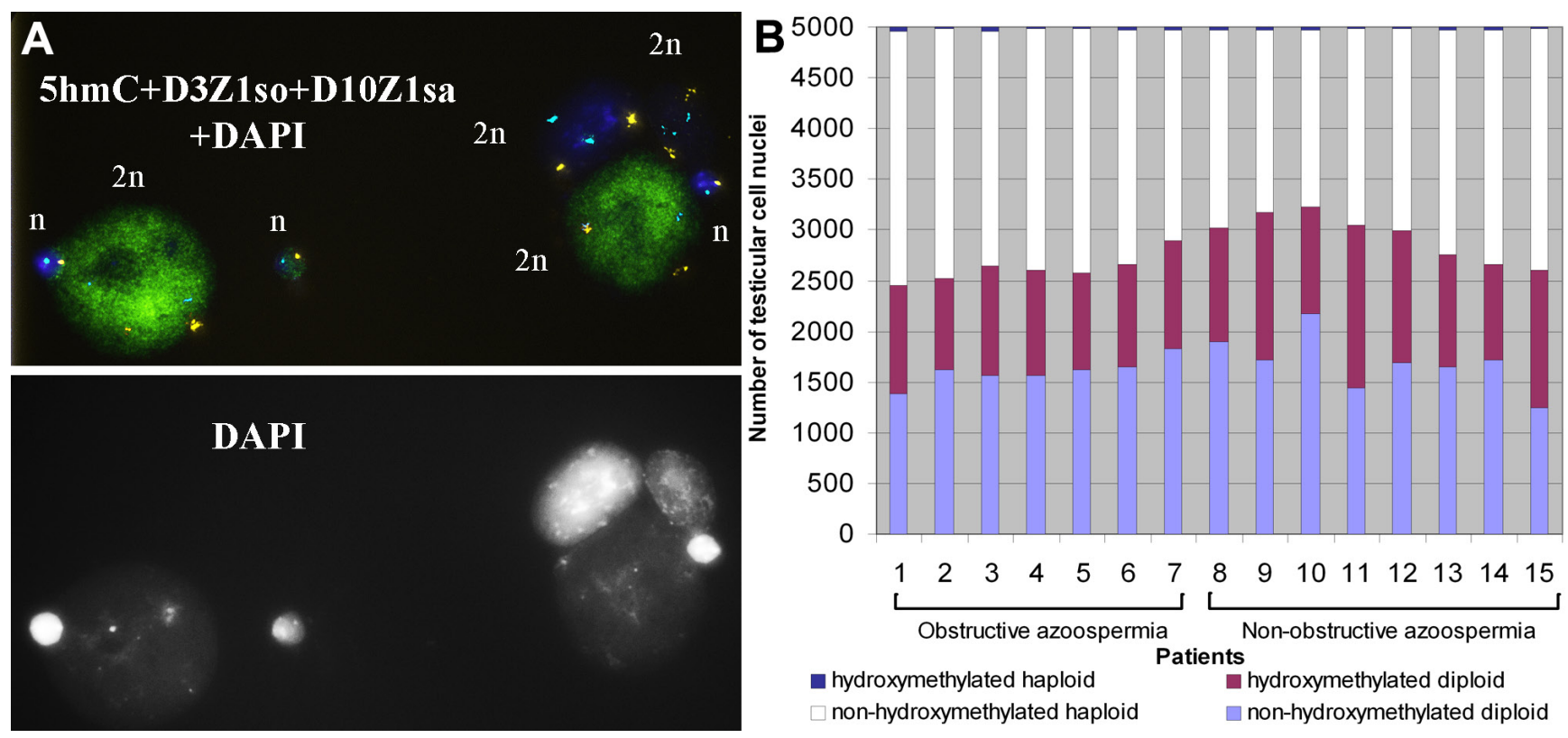

Figure 6: 5-hydroxymethylcytosine $(5 \mathrm{hmC})$ patterns in nuclei of human testicular cells. A. The haploid and diploid nuclei of testicular cells after subsequent fluorescence in situ hybridization (FISH) with DNA probes specific for centromere 3 (3p11.1-q11.1 = D3Z1, SpectrumOrange) and $10(10 \mathrm{p} 11.1-\mathrm{q} 11.1=\mathrm{D} 10 \mathrm{Z1}$, SpectrumAqua) and immunostaining for 5hmC/Alexa488 (green) with DAPI counterstaining. In the shown field of view, two out of four diploid nuclei and one out of three haploid nuclei are hydroxymethylated, whereas in the rest nuclei $5 \mathrm{hmC}$ is undetectable. B. The proportions of non-hydroxymethylated diploid, hydroxymethylated diploid, nonhydroxymethylated haploid and hydroxymethylated haploid nuclei among a total of 5000 nuclei in each of testicular tissue samples from 15 azoospermic patients. The proportions of nucleus types do not differ between patients with obstructive and non-obstructive azoospermia $(\mathrm{P}=0.978$, Fisher's z-test $)$.
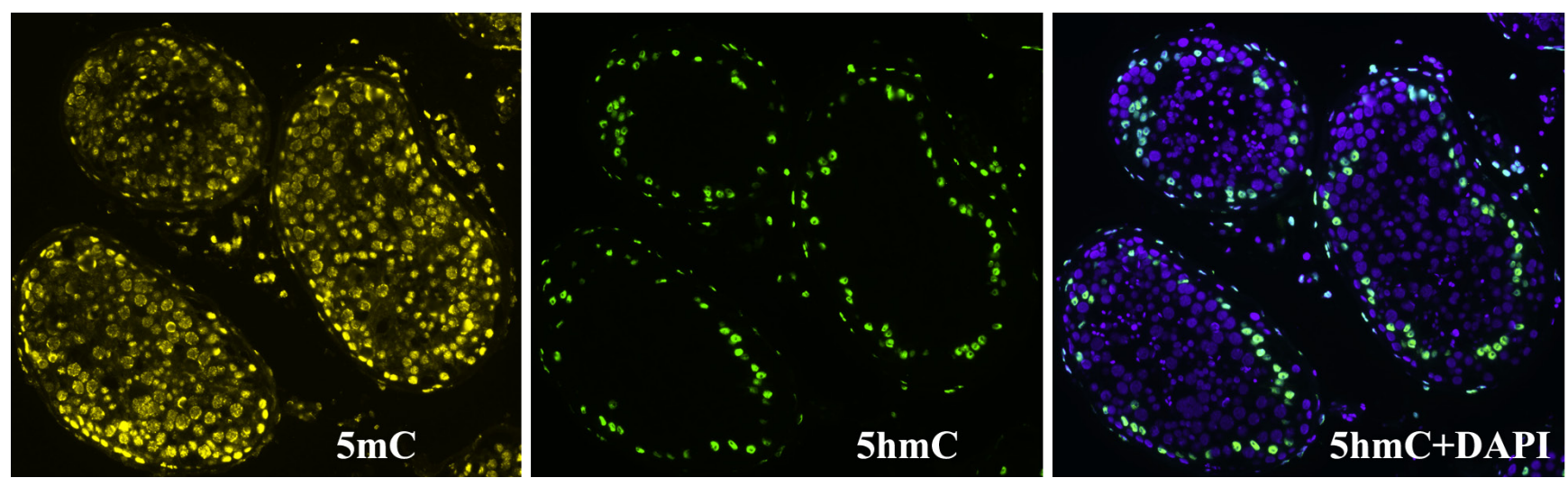

Figure 7: Immunohistochemical detection of 5-methylcytosine $(5 \mathrm{mC})$ and 5-hydroxymethylcytosine $(5 \mathrm{hmC})$ patterns in a tubular cross section. $5 \mathrm{mC}$ is visible in nuclei of all cell types within the tubules, while $5 \mathrm{hmC}$ is present mostly in spermatogonia Ad lying next to the basal membrane. 
locates almost exclusively in nuclei of spermatogonia $\mathrm{Ad}$ and in nuclei of only a few spermatids.

\section{5-hydroxymethylcytosine and 5-methylcytosine patterns in unfertilized oocytes}

We have analyzed $5 \mathrm{hmC}$ and $5 \mathrm{mC}$ patterns in unfertilized human oocytes. Unfertilized oocytes were fixed on glass slides and meiotic chromosomes at metaphase II stage were available for analysis. In contrast to meiotic spermatocytes and most mature spermatozoa, $5 \mathrm{mC}$ and $5 \mathrm{hmC}$ levels in oocyte chromosomes were comparable. Chromosomes were densely methylated and hydroxymethylated along arms with the only exception of pericentric regions, which contained neither $5 \mathrm{mC}$ nor $5 \mathrm{hmC}$ (Figure 8). This pattern contrasted sharply to that in spermatocyte metaphase II chromosomes, which featured methylation along arms, including pericentric regions, and absence of hydroxymethylation (Figure 5).

\section{DISCUSSION}

The role of epigenetics in human reproduction is being intensively studied. Recent studies have provided evidence that aberrantly changed $5 \mathrm{mC}$ patterns in sperm are associated with male infertility [27-29]. In the present study, we focus on $5 \mathrm{hmC}$ - an oxidative derivative of $5 \mathrm{mC}$ which can appear during programmed genome epigenetic changes or in response to endo- and exogenous factors. We report immunofluorescently detected $5 \mathrm{hmC}$ patterns in human ejaculated spermatozoa and in testicular spermatogenic cells, considering their DNA methylation status. We show that $5 \mathrm{mC}$ is present throughout studied stages of spermatogenesis. In contrast to $5 \mathrm{mC}, 5 \mathrm{hmC}$ is present either at high or at extremely low / undetectable level in both ejaculated spermatozoa and testicular spermatogenic cells (Figure 1, 5, 6A). The presence of high $5 \mathrm{hmC}$ level in some, but not all germ cells, raises a question about the reasons for such pattern.

Based on our findings, we suggest that a higher frequency of $5 \mathrm{hmC}$-positive spermatozoa indicates poor semen quality. Firstly, an increase in highly hydroxymethylated spermatozoa frequency in ejaculate is more typical for patients from infertile couples than for healthy sperm donors. Secondly, the frequency of $5 \mathrm{hmC}$ positive spermatozoa correlates strongly negatively with some indicators of good semen quality (morphologically normal spermatozoa and normal-head spermatozoa) and strongly positively with sperm DNA fragmentation, which is an indicator of poor semen quality. Thus, an increase in frequency of highly hydroxymethylated spermatozoa may be associated with fertility impairment.

An essential question is by what mechanism spermatozoa acquire $5 \mathrm{hmC}$. There are two pathways of $5 \mathrm{hmC}$ formation - by programmed TET-mediated $5 \mathrm{mC}$ oxidation [11] and by a random hydroxyl radical attack on $5 \mathrm{mC}$ under oxidative stress conditions [34, 35]. In ejaculated spermatozoa, TET mRNA levels are significantly reduced in subfertile patients [36], indicating the possibility that a high sperm hydroxymethylation may be spontaneously induced by reactive oxygen species (ROS) attack and not by enzymatic regulation. Elevated DNA methylation level in highly hydroxymethylated spermatozoa detected in our study also suggests that $5 \mathrm{hmC}$ is not formed through $5 \mathrm{mC}$ oxidation by TETs, which is usually accompanied by a decrease in $5 \mathrm{mC}$ level. Occurrence of high sperm DNA fragmentation, which is mostly caused by ROS [37-39], in patients with elevated rates of $5 \mathrm{hmC}$-positive spermatozoa is in favor of ROSinduced sperm hydroxylation as well.

The other issue to address is the stage of spermatogenesis at which a high $5 \mathrm{hmC}$ level is aberrantly induced in spermatozoa. We show that during spermatogenesis, hydroxymethylation is present in interphase spermatogonia Ad, is absent in all mitotic spermatogonial chromosomes, interphase spermatogonia $\mathrm{Ap}$ and B and spermatocyte meiotic chromosomes, and then appears again postmeiotically in a minor population of spermatids. This picture of $5 \mathrm{hmC}$ distribution does not vary significantly among azoospermic patients. Thus, hydroxymethylation pattern seems to undergo programmed genome-wide alterations in differentiating spermatogenic cells. During post-testicular sperm maturation, spermatozoa have strongly decreased amount of cytoplasm which makes their genetic and epigenetic patterns highly vulnerable to internal and external factors, including ROS [23, 40]. Therefore, we hypothesize that a high $5 \mathrm{hmC}$ level in individual ejaculated spermatozoa results from spontaneous post-testicular

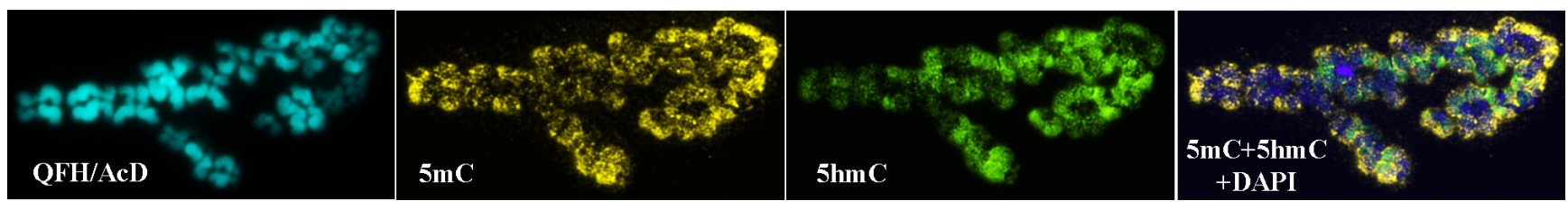

Figure 8: Human meiotic oocyte after QFH/AcD staining and immunodetection of 5-methylcytosine (5mC) and

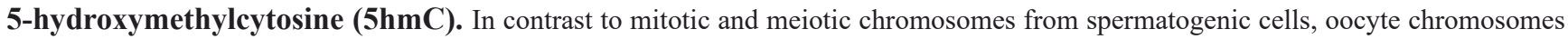
are methylated and hydroxymethylated along arms. QFH/AcD staining and photoimaging of banded chromosomes were performed before the $5 \mathrm{hmC}$ and $5 \mathrm{mC}$ immunodetection. 
hydroxymethylation rather than programmed epigenetic changes.

Interestingly, in hierarchically organized human adult tissues, the lowest $5 \mathrm{hmC}$ levels are typical for stem/ progenitor cells and the highest levels - for terminally differentiated cells [41]. The analysis of testicular cytogenetic and histological preparations in the present study and histological sections by Nettersheim et al. [42] shows that human testicular tissue is characterized by a different picture: by a high $5 \mathrm{hmC}$ level in stem cell spermatogonia Ad and a generally low $5 \mathrm{hmC}$ level at the further stages of differentiation. Spermatogenic cells have been supposed to lose $5 \mathrm{hmC}$ passively (in a replication-dependent manner) during mitotic/meiotic divisions [36, 42]. However, visualization of mitotic and meiotic chromosomes in our study shows a $5 \mathrm{mC}$ pattern similar to that reported previously in human lymphocytes and embryonic tissues [43-47] and no 5hmC (Figure 5). In neither of the $>1200$ chromosome spreads did we observe hydroxymethylation asymmetry in sister chromatids, which is a major sign of $5 \mathrm{hmC}$ passive loss, as shown in blastomeres of preimplantation embryos and in some somatic cells [48-51]. This suggests that $5 \mathrm{hmC}$ elimination from spermatogonia Ad most probably occurs before they enter mitosis to form spermatogonia Ap. It is noteworthy that oocyte meiotic chromosomes are characterized by high $5 \mathrm{hmC}$ and $5 \mathrm{mC}$ levels (Figure 8), thus, indicating strong sex-specific differences in gamete hydroxymethylation and methylation.

In conclusion, in human spermatogenesis, there seem to be two types of $5 \mathrm{hmC}$ pattern alterations: those strictly determined by germline-specific reprogramming in testicular tissue and those sporadically induced by endo- and exogenous factors in individual posttesticular spermatozoa. The immunocytochemically detected percentage of these highly hydroxymethylated spermatozoa in ejaculate is associated with fertility status and sperm parameters and, thus, can be suggested as a novel indicator of semen quality. The use of epigenetic analysis for categorization of infertile patients is supposed to significantly improve diagnostic approaches in the field of male reproduction [52, 53]. Moreover, understanding the mechanisms involved in epigenetic alterations opens the way for targeted treatment of pathological conditions $[54,55]$. We believe that our findings are potentially significant for diagnosis and treatment of male infertility.

\section{MATERIALS AND METHODS}

\section{Collection of testicular tissue samples, sperm and oocytes}

Testicular tissue samples were obtained by open biopsy from 15 patients (24-54 yrs, mean $37.1 \pm 2.29)$ diagnosed with azoospermia. Of 15 patients, 7 had obstructive and 8 non-obstructive azoospermia. Immediately after sampling, the testicular tissue fragments were placed in Petri dish with Flushing medium (Origio, 10845060, Denmark), released from blood clots under the Leica M125 stereomicroscope, and stored no longer than $1 \mathrm{hr}$ at room temperature before treatments for cytogenetic slide preparation.

Semen samples were obtained from 13 sperm

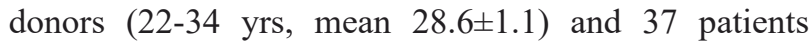
from infertile couples (21-53 yrs, mean $34.9 \pm 1.05)$ by masturbation after 3-5 days of abstinence period. The sperm donors were physically and mentally healthy had normal karyotype and the following semen characteristics at the time of collection: volume $\geq 2 \mathrm{ml}$, concentration $\geq 64$ millions $/ \mathrm{ml}$, progressive motility $\geq 49 \%$, normal morphology (according to [56]) $\geq 6 \%$, cryotolerance $\geq 50$ $\%$. The inclusion criteria for patients were infertility in a couple (failure to achieve pregnancy after a year of regular, unprotected intercourse) and normal karyotype, considering the possible effect of karyotype abnormalities on cell epigenetic status and DNA fragmentation [57-59]. The somatic karyotyping of the patients was performed by QFH-banding/actinomycin D (AcD) counterstaining of lymphocyte metaphase spreads according to the protocol repeatedly used in our center $[60,61]$. Microdeletion analysis in Yq11 was performed and showed no alterations of AZF region in either patient. A conventional semen analysis (volume, $\mathrm{pH}$, concentration, motility, vitality, and morphology) was performed according to WHO recommendations [62] and revealed normospermic $(n=$ $21)$, asthenozoospermic $(n=5)$, oligoasthenozoospermic $(n=2)$ and teratozoospermic $(n=9)$ individuals among the patients. Spermiogram parameters of patients and sperm donors are summarized in Table 1.

Unfertilized oocytes were selected for the study as described previously [51]. After hormonal stimulation, oocytes were aspirated from patients' follicles, rinsed in Flushing Medium (Origio, 10845060, Denmark) and incubated for $3 \mathrm{hrs}$ in the ISM1 medium (Origio, 10500060 , Denmark) at $+37^{\circ} \mathrm{C}$ in an atmosphere of 5 $\% \mathrm{CO}_{2}$. Then, routinely prepared sperm was added for in vitro fertilization and after $20 \mathrm{hrs}$, the presence of pronuclei was examined. A total of 23 unfertilized oocytes were selected for the study.

The biological samples were obtained at the Department of Assisted Reproductive Technologies, D.O. Ott Research Institute of Obstetrics, Gynecology and Reproductology, in AVA-Peter Clinic and in Aimed Clinic (St. Petersburg, Russian Federation). The study was approved by the Ethics committee of D.O. Ott Research Institute of Obstetrics, Gynecology and Reproductology. All the samples were enrolled in the study after patients signed the informed consent. The study was performed in accordance with the Declaration of Helsinki. 


\section{Cytogenetic slide preparation}

Chromosomes and nuclei from the testicular tissue samples were fixed on glass slides by the direct technique (without in vitro culture) [63]. Shortly, testicular tissue fragments were incubated in hypotonic solution (0.9 $\%$ sodium citrate) with colchicines $(2.5 \mu \mathrm{g} / \mathrm{ml})$ at room temperature for 60-80 min and then in fixative (methanol : glacial acetic acid, $3: 1)$ at $+4{ }^{\circ} \mathrm{C}$ for $90 \mathrm{~min}$. Then they were macerated in drops of $60 \%$ acetic acid on glass slides. After saturation with cells, drops of $60 \%$ acetic acid were spread on the slides, fixed with 2-3 drops of fixative (methanol : glacial acetic acid, 3:1) and air-dried.

Sperm slides were prepared from $1 \mathrm{ml}$ aliquots of native semen samples as described previously [51]. The semen samples were treated with hypotonic solution $(0.9 \%$ sodium citrate) at room temperature for $20 \mathrm{~min}$. Then, they were incubated at $+4{ }^{\circ} \mathrm{C}$ in freshly prepared fixative (methanol : glacial acetic acid, 3:1), which was changed at least twice during a $60 \mathrm{~min}$ fixation period. The suspension was concentrated by centrifugation and dropped onto slides. The slides were air dried at room temperature.

Oocyte chromosome preparations were made according to the fixation protocol for single cells [64]. Unfertilized oocytes were treated with $0.1 \%$ colchicines for 6-12 hrs prior fixation, incubated for 10-30 $\mathrm{s}$ in a drop of $0.9 \%$ sodium citrate supplemented with $1 \%$ protease, washed in $0.9 \%$ sodium citrate solution, and fixed on the slides with freshly prepared cold fixative (methanol : glacial acetic acid, 3:1).

\section{Tissue slide preparation}

Tubular cross section slides were prepared from the testicular tissue fragments which had not been used for cytogenetic preparations and had been stored in fixative (methanol : glacial acetic acid, 3:1). Such tissue fragments were available from 5 patients. The tissue fragments were transferred to $10 \%$ formalin and incubated for 24 hrs. Then, the tissue fragments were washed in flowing water for $30 \mathrm{~min}$ and processed for paraffin embedding in Logos J (Milestone, Italy) as recommended by the manufacturer. $2.5 \mu \mathrm{m}$ thick tissue sections were cut on a rotary microtome HM 340E (Thermo Scientific, Germany) and placed on Superfrost Plus glass slides. After incubating the slides at $+37{ }^{\circ} \mathrm{C}$ overnight, heatinduced epitope retrieval was performed in the PT-Module (Thermo Scientific, Germany) in a recommended buffer $(\mathrm{pH}=6)$ (Thermo Scientific, Germany) at $+98{ }^{\circ} \mathrm{C}$ for 30 $\mathrm{min}$. Then, buffer with the slides was cooled down to +65 ${ }^{\circ} \mathrm{C}$, and the slides were transferred to room temperature $1 x$ PBS for subsequent immunostaining.
FISH

To determine nuclei ploidy, FISH was performed on the testicular cytogenetic preparations according to standard procedures with minor modifications [65]. After aging at $+55^{\circ} \mathrm{C}$ overnight, the slides were dehydrated in ethanol series $(70 \%, 80 \%$ and $95 \%)$, washed in $4 \mathrm{xSSC}$ at $+37^{\circ} \mathrm{C}$ for $3 \mathrm{~min}$, incubated in $0.01 \%$ pepsin solution at $+37{ }^{\circ} \mathrm{C}$ for $25 \mathrm{~min}$ and washed again in $4 \mathrm{xSSC}$ at $+37{ }^{\circ} \mathrm{C}$ for $3 \mathrm{~min}$. Then, the slides were fixed in $2.5 \%$ paraformaldehyde $2 \mathrm{xSSC}$ solution at room temperature for $10 \mathrm{~min}$, washed in two changes of fresh $4 \mathrm{xSSC}$ at +37 ${ }^{\circ} \mathrm{C}$ for $3 \mathrm{~min}$, rinsed in distilled water and dehydrated in ethanol series. $10 \mu \mathrm{l}$ of hybridization mixture was then applied to each slide, covered with $22 \times 22 \mathrm{~mm}$ coverslip and sealed with rubber cement. Two DNA-probes were used: Vysis CEP 3 (D3Z1) SpectrumOrange Probe (3p11.1-q11.1 Alpha Satellite DNA) and Vysis CEP 10 SpectrumAqua Probe (10p11.1-q11.1) (Abbott Molecular, USA). The use of two DNA-probes instead of one helps to avoid misinterpretation of the hybridization picture, when a diploid nucleus with an occasional loss of one chromosome can be classified as a haploid one. The slides with sample and probe mixture were denatured for $10 \mathrm{~min}$ at $+78{ }^{\circ} \mathrm{C}$ and then hybridized for at least 12 hrs at $+37{ }^{\circ} \mathrm{C}$ in Thermobrite. Then, rubber cement was carefully removed and the slides were washed in $4 \mathrm{xSSC}$, supplemented with Tween $20(0.5 \%)$ at $+37{ }^{\circ} \mathrm{C}$ until coverslips off. The slides were washed in two changes of $4 \mathrm{xSSC}$ at $+37^{\circ} \mathrm{C}$ for $3 \mathrm{~min}$, rinsed in distilled water, dehydrated in ethanol series and air-dried.

\section{Immunodetection of $5 \mathrm{hmC}$ and $5 \mathrm{mC}$}

The immunodetection of $5 \mathrm{hmC}$ and $5 \mathrm{mC}$ was performed using primary antibodies against $5 \mathrm{hmC}$ (rabbit polyclonal, Active Motif, 39769, USA) and 5mC (mouse monoclonal, Millipore, clone 33D3, MABE146, USA) and secondary goat anti-rabbit Alexa Fluor 488 (Life Technologies, A-11008) and goat anti-mouse Alexa Fluor 594 (Life Technologies, A-11005, USA) / Alexa Fluor 555 (Life Technologies, A-21424, USA) antibodies according to the protocol used previously [53]. The preparations were denatured in $2 \mathrm{M} \mathrm{HCl}$ for $20-30 \mathrm{~min}$ at room temperature, washed in ice-cold PBS and distilled water and incubated with blocking solution (1\% BSA, $0.1 \%$ Tween 20 in PBS) for $30-40 \mathrm{~min}$ at $+37^{\circ} \mathrm{C}$ in a humidified chamber. Then, the mixture of primary antibodies diluted in blocking solution (1:500) was applied to the slides for $90 \mathrm{~min}$ at room temperature in the humidified chamber. On the negative control slides, the primary antibody step was omitted. The slides were washed thrice with PBS for 15 min each, supplemented with $0.5 \%$ Tween 20 at $+43{ }^{\circ} \mathrm{C}$ in a shaking bath and the mixture of secondary antibodies, diluted in blocking solution (1:200) was applied to the 
slides for $60 \mathrm{~min}$ at $+37^{\circ} \mathrm{C}$ in the humidified chamber. The slides were then washed thrice with PBS for 15 min each supplemented with $0.5 \%$ Tween 20 at $+43{ }^{\circ} \mathrm{C}$ in the shaking bath, rinsed in PBS and distilled water, dehydrated in the ethanol series $(70,80$, and $96 \%)$, and mounted in DAPI-containing Vectashield antifade (Vector Laboratories, H-1200, USA).

For simultaneous analysis of $5 \mathrm{hmC}$ patterns and nuclei ploidy on the cytogenetic slides, FISH was performed prior to the immunodetection of $5 \mathrm{hmC}$. In this case, the step of DNA denaturation was omitted in the immunodetection protocol, as denaturation was performed earlier during the FISH procedures. The step of DNA denaturation in the immunodetection protocol was also omitted for the histological slide preparations.

DNA hydroxymethylation and methylation patterns were first analyzed qualitatively based on visual assessment of $5 \mathrm{hmC}$ or $5 \mathrm{mC}$ presence/absence in testicular cells and ejaculated spermatozoa. In testicular cells, the $5 \mathrm{hmC}$ and $5 \mathrm{mC}$ patterns were analyzed in 5000 nuclei and in 15-25 chromosome spreads from mitotic spermatogonia at metaphase stage, meiotic spermatocyte at prophase I (pachytene, diplotene, and diakinesis) and metaphase II stages from each of 15 azoospermic patients. Diploid nucleus was considered to be from spermatogonium Ad, if a large central vacuole-like cavity was detected [33]. All haploid nuclei were considered to be from postmeiotic spermatogenic cells. In ejaculates, $5 \mathrm{hmC}$ and $5 \mathrm{mC}$ patterns were analyzed in 5000 spermatozoa from each of 37 patients and 13 sperm donors. After visual analysis, the measurements of anti-5hmC and anti-5mC fluorescence intensity were performed on the representative digital images of $3005 \mathrm{hmC}$-positive and $3005 \mathrm{hmC}$-negative spermatozoa from 3 individuals. The intensity of fluorescence was calculated in arbitrary units (a.u.) for each spermatozoa using Image J 1.48v software.

\section{TUNEL}

To assess sperm DNA integrity, TUNEL was performed on the sperm slides according to the protocol reported previously [66], with modifications. The preparations were washed twice in $1 \mathrm{xPBS}$ for 5 min each and then additionally fixed in $4 \%$ paraformaldehyde for $10 \mathrm{~min}$ at room temperature. The preparations were permeabilized by treatment with $0.1 \%$ Triton X-100 in $0.1 \%$ sodium citrate for $15 \mathrm{~min}$ at $+4{ }^{\circ} \mathrm{C}$. Then, the slides were washed twice in $1 \times$ PBS for 5 min each at room temperature and a reagent mixture $(4.5 \mu \mathrm{l}$ of nucleotide mixture in reaction buffer $+0.5 \mu \mathrm{l}$ of enzyme (terminal deoxynucleotidyl transferase from calf thymus, recombinant in E. coli, in storage buffer, Roche, Germany) was added. After incubation for $1 \mathrm{~h}$ at $+37{ }^{\circ} \mathrm{C}$ in the humidified chamber, the slides were washed thrice in 1xPBS for $5 \mathrm{~min}$ each at room temperature, rinsed with distilled water, dehydrated in the ethanol series $(70,80$, and $96 \%$ ), and mounted in DAPI-containing Vectashield antifade (Vector Laboratories, USA). The presence of single- and double-strand breaks in DNA was registered by a microscopically detected fluorescent signal in the sperm head. To calculate the percentage of sperm with fragmented DNA, a total of 2000 sperm heads were analyzed in each sample.

\section{Image acquisition}

Fluorescence images were acquired using a Leica DMLS microscope with a Leica DFC320 camera and Leica DFC Twain software (for QFH/AcD banded chromosomes), as well as a Leica DM 2500 microscope with SOR, SGR, SRE and A filtercubes, a Leica DFC345 FX camera and Leica Application SuiteV.3.8.0 software (for phase contrast, FISH, immunostained, and DAPIstained preparations). Time of exposition for images was up to $5.5 \mathrm{~s}$ for $5 \mathrm{hmC}$ (green), up to $2 \mathrm{~s}$ for $5 \mathrm{mC}$ (orange/red). Individual images were processed in Adobe Photoshop CS3 with "crop", "brightness/contrast" and "sharpen" instruments applied to the whole image.

\section{Statistical analysis}

The statistical analysis was performed using GraphPad Prism, Version 6.01 and Microsoft Office Excel 2003 SP2. Values are shown as mean and range (minimum to maximum) for semen parameters, and as mean and standard deviation (SD) for testicular cell nuclei counts. Data distribution was evaluated by the D'Agostino-Pearson test. Non-parametric variables were compared using the Mann-Whitney U-test. The correlation coefficients were calculated using the nonparametric Spearman test. The proportions of hydroxymethylated and non-hydroxymethylated diploid and haploid nuclei from testicular samples of patients with obstructive and nonobstructive azoospermia were compared using Fisher's z-test. The $\alpha$-level was set at 0.05 .

\section{Author contributions}

AAP, OAE, AVT, IDM and VSB designed the study; IDM, EMK, ISS, SAS and OSG recruited patients and donors and collected material; OGC made oocyte chromosome preparations; OAE, AAP, AVT, SEP, OGC, MIK and IAG made cytogenetic and histological preparations and performed immunofluorescent detection of $5 \mathrm{hmC}$ and $5 \mathrm{mC}$ under the supervision of TVK; AVT, SEP, IAG, OAE and AAP undertook microscopic analysis of immunostained preparations; IDF, EMK, ISS, SAS and MAM performed conventional semen analysis and TUNEL under the supervision of IYK and AMG; SEP and EVD performed statistical analysis; AAP, OAE, 
AVT, EVD, OGC, MIK, OSG, TVK, IYK and AMG conducted the literature search and interpreted the data; OAE and AAP wrote the manuscript; VSB coordinated the work; IYK, AMG, TVK and VSB critically revised the manuscript for important intellectual content. All the authors approved the final version of the manuscript.

\section{ACKNOWLEDGMENTS}

The authors are grateful to Ksenia O. Khudadyan for helpful advice during preparation of the manuscript.

\section{CONFLICTS OF INTEREST}

The authors declare that there is no conflict of interest.

\section{FUNDING}

The study of $5 \mathrm{hmC}$ and $5 \mathrm{mC}$ patterns in oocytes and mature sperm was supported by Russian Foundation of Basic Research, grant number 16-34-60107 mol a $\mathrm{dk}$. The study of $5 \mathrm{hmC}$ and $5 \mathrm{mC}$ patterns in testicular spermatogenic cells and the correlation studies were supported by Russian Foundation of Basic Research, grant number 16-34-00532 mol_a. The recruitment of sperm donors, which included mental and physical examination (questionnaires, karyotyping, testing for monogenic disorders) of a cohort of applicants, was supported by Russian Science Foundation, grant number 14-50-00069.

OAE, AVT and EMK are grantees of RF President Scholarship.

\section{REFERENCES}

1. Reik W, Surani MA. Germline and Pluripotent Stem Cells. Cold Spring Harb Perspect Biol. 2015; 7.

2. Seisenberger S, Peat JR, Hore TA, Santos F, Dean W, Reik W. Reprogramming DNA methylation in the mammalian life cycle: building and breaking epigenetic barriers. Philos Trans R Soc Lond B Biol Sci. 2013; 368: 20110330.

3. Marcho C, Cui W, Mager J. Epigenetic dynamics during preimplantation development. Reproduction. 2015; 150: R109-20.

4. White CR, MacDonald WA, Mann MR. Conservation of DNA Methylation Programming Between Mouse and Human Gametes and Preimplantation Embryos. Biol Reprod. 2016; 95: 61.

5. Lee HJ, Hore TA, Reik W. Reprogramming the methylome: erasing memory and creating diversity. Cell Stem Cell. 2014; 14: 710-719.

6. Zheleznyakova GY, Voisin S, Kiselev AV, Sällman Almén M, Xavier MJ, Maretina MA, Tishchenko LI, Fredriksson R, Baranov VS, Schiöth HB. Genome-wide analysis shows association of epigenetic changes in regulators of Rab and
Rho GTPases with spinal muscular atrophy severity. Eur J Hum Genet. 2013; 21: 988-993.

7. Skryabin NA, Tolmacheva EN, Lebedev IN, Zavyalova MV, Slonimskaya EM, Cherdyntseva NV. Dynamics of aberrant methylation of functional groups of genes in progression of breast cancer. Molecular Biology. 2013; 47: 267-274.

8. Nazarenko MS, Markov AV, Lebedev IN, Freidin MB, Sleptcov AA, Koroleva IA, Frolov AV, Popov VA, Barbarash OL, Puzyrev VP. A comparison of genomewide DNA methylation patterns between different vascular tissues from patients with coronary heart disease. PLoS One. 2015; 10: e0122601.

9. Zheleznyakova GY, Nilsson EK, Kiselev AV, Maretina MA, Tishchenko LI, Fredriksson R, Baranov VS, Schiöth HB. Methylation levels of SLC23A2 and NCOR2 genes correlate with spinal muscular atrophy severity. PLoS One. 2015; 10: e0121964.

10. Mahalingaiah PK, Ponnusamy L, Singh KP. Oxidative stress-induced epigenetic changes associated with malignant transformation of human kidney epithelial cells. Oncotarget. 2017; 8: 11127-11143. doi: 10.18632/oncotarget.12091.

11. Tahiliani M, Koh KP, Shen Y, Pastor WA, Bandukwala H, Brudno Y, Agarwal S, Iyer LM, Liu DR, Aravind L, Rao A. Conversion of 5-methylcytosine to 5-hydroxymethylcytosine in mammalian DNA by MLL partner TET1. Science. 2009; 324: 930-935.

12. Ito S, Shen L, Dai Q, Wu SC, Collins LB, Swenberg JA, He C, Zhang Y. Tet proteins can convert 5-methylcytosine to 5-formylcytosine and 5-carboxylcytosine. Science. 2011; 333: 1300-1303.

13. Branco MR, Ficz G, Reik W. Uncovering the role of 5-hydroxymethylcytosine in the epigenome. Nat Rev Genet. 2011; 13: 7-13.

14. Pfeifer GP, Kadam S, Jin SG. 5-hydroxymethylcytosine and its potential roles in development and cancer. Epigenetics Chromatin. 2013; 6: 10.

15. Efimova OA, Pendina AA, Tikhonov AV, Kuznetzova TV, Baranov VS. Oxidized form of 5-methylcytosine 5-hydroxymethylcytosine: a new insight into the biological significance in the mammalian genome. Russian Journal of Genetics: Applied Research. 2015; 5: 75-81.

16. Carrell DT, Hammoud SS. The human sperm epigenome and its potential role in embryonic development. Mol Hum Reprod. 2010; 16: 37-47.

17. Jenkins TG, Carrell DT. The sperm epigenome and potential implications for the developing embryo. Reproduction. 2012; 143: 727-734.

18. Gannon JR, Emery BR, Jenkins TG, Carrell DT. The sperm epigenome: implications for the embryo. Adv Exp Med Biol. 2014; 791: 53-66.

19. Jablonka E. Epigenetic inheritance and plasticity: The responsive germline. Prog Biophys Mol Biol. 2013; 111: 99-107. 
20. Feng L, Chen X. Epigenetic regulation of germ cells remember or forget? Curr Opin Genet Dev. 2015; 31: 2027.

21. Heller CG, Clermont Y. Spermatogenesis in man: an estimate of its duration. Science. 1963; 140: 184-186.

22. Heller CG, Clermont Y. Kinetics of the germinal epithelium in man. Recent Prog Horm Res. 1964; 20: 545-571.

23. Aitken RJ, Gibb Z, Baker MA, Drevet J, Gharagozloo $P$. Causes and consequences of oxidative stress in spermatozoa. Reprod Fertil Dev. 2016; 28: 1-10.

24. Jenkins TG, Aston KI, Meyer TD, Hotaling JM, Shamsi MB, Johnstone EB, Cox KJ, Stanford JB, Porucznik CA, Carrell DT. Decreased fecundity and sperm DNA methylation patterns. Fertil Steril. 2016; 105: 51-57.

25. Milekic MH, Xin Y, O’Donnell A, Kumar KK, BradleyMoore M, Malaspina D, Moore H, Brunner D, Ge Y, Edwards J, Paul S, Haghighi FG, Gingrich JA. Agerelated sperm DNA methylation changes are transmitted to offspring and associated with abnormal behavior and dysregulated gene expression. Mol Psychiatry. 2015; 20: 995-1001.

26. Skinner MK, Guerrero-Bosagna C, Haque MM. Environmentally induced epigenetic transgenerational inheritance of sperm epimutations promote genetic mutations. Epigenetics. 2015; 10: 762-771.

27. Aston KI, Uren PJ, Jenkins TG, Horsager A, Cairns BR, Smith AD, Carrell DT. Aberrant sperm DNA methylation predicts male fertility status and embryo quality. Fertil Steril. 2015; 104: 1388-1397.e1-5.

28. Du Y, Li M, Chen J, Duan Y, Wang X, Qiu Y, Cai Z, Gui $\mathrm{Y}$, Jiang H. Promoter targeted bisulfite sequencing reveals DNA methylation profiles associated with low sperm motility in asthenozoospermia. Hum Reprod. 2016; 31: 2433.

29. Urdinguio RG, Bayón GF, Dmitrijeva M, Toraño EG, Bravo C, Fraga MF, Bassas L, Larriba S, Fernández AF. Aberrant DNA methylation patterns of spermatozoa in men with unexplained infertility. Hum Reprod. 2015; 30: 101428.

30. Jenkins TG, Aston KI, Cairns BR, Carrell DT. Paternal aging and associated intraindividual alterations of global sperm 5-methylcytosine and 5-hydroxymethylcytosine levels. Fertil Steril. 2013; 100: 945-951.

31. Guz J, Gackowski D, Foksinski M, Rozalski R, Olinski R. Comparison of the absolute level of epigenetic marks 5-methylcytosine, 5-hydroxymethylcytosine, and 5-hydroxymethyluracil between human leukocytes and sperm. Biol Reprod. 2014; 91: 55.

32. Wang XX, Sun BF, Jiao J, Chong ZC, Chen YS, Wang XL, Zhao Y, Zhou YM, Li D. Genome-wide 5 -hydroxymethylcytosine modification pattern is a novel epigenetic feature of globozoospermia. Oncotarget. 2015; 6: 6535-6543. doi: 10.18632/oncotarget.3163.

33. Clermont Y. The cycle of the seminiferous epithelium in man. Am J Anat. 1963; 112: 35-51.

34. Madugundu GS, Cadet J, Wagner JR. Hydroxyl-radicalinduced oxidation of 5-methylcytosine in isolated and cellular DNA. Nucleic Acids Res. 2014; 42: 7450-7460.

35. Cadet J, Wagner JR. Radiation-induced damage to cellular DNA: Chemical nature and mechanisms of lesion formation. Radiation Physics and Chemistry. 2016; 128: 5459.

36. Ni K, Dansranjavin T, Rogenhofer N, Oeztuerk N, Deuker J, Bergmann M, Schuppe HC, Wagenlehner F, Weidner $\mathrm{W}$, Steger K, Schagdarsurengin U. TET enzymes are successively expressed during human spermatogenesis and their expression level is pivotal for male fertility. Hum Reprod. 2016; 31: 1411-1424.

37. Lopes S, Jurisicova A, Sun JG, Casper RF. Reactive oxygen species: potential cause for DNA fragmentation in human spermatozoa. Hum Reprod. 1998; 13: 896-900.

38. Aitken RJ, Gordon E, Harkiss D, Twigg JP, Milne P, Jennings Z, Irvine DS. Relative impact of oxidative stress on the functional competence and genomic integrity of human spermatozoa. Biol Reprod. 1998; 59: 1037-1046.

39. Barroso G, Morshedi M, Oehninger S. Analysis of DNA fragmentation, plasma membrane translocation of phosphatidylserine and oxidative stress in human spermatozoa. Hum Reprod. 2000; 15: 1338-1344.

40. Sakkas D, Alvarez JG. Sperm DNA fragmentation: mechanisms of origin, impact on reproductive outcome, and analysis. Fertil Steril. 2010; 93: 1027-1036.

41. Haffner MC, Chaux A, Meeker AK, Esopi DM, Gerber J, Pellakuru LG, Toubaji A, Argani P, Iacobuzio-Donahue C, Nelson WG, Netto GJ, De Marzo AM, Yegnasubramanian S. Global 5-hydroxymethylcytosine content is significantly reduced in tissue stem/progenitor cell compartments and in human cancers. Oncotarget. 2011; 2: 627-637. doi: 10.18632/oncotarget.316.

42. Nettersheim D, Heukamp LC, Fronhoffs F, Grewe MJ, Haas N, Waha A, Honecker F, Waha A, Kristiansen G, Schorle $\mathrm{H}$. Analysis of TET expression/activity and $5 \mathrm{mC}$ oxidation during normal and malignant germ cell development. PLoS One. 2013; 8: e82881.

43. Barbin A, Montpellier C, Kokalj-Vokac N, Gibaud A, Niveleau A, Malfoy B, Dutrillaux B, Bourgeois CA. New sites of methylcytosine-rich DNA detected on metaphase chromosomes. Hum Genet. 1994; 94: 684-692.

44. Kokalj-Vokac N, Zagorac A, Pristovnik M, Bourgeois CA, Dutrillaux B. DNA methylation of the extraembryonic tissues: an in situ study on human metaphase chromosomes. Chromosome Res. 1998; 6: 161-166.

45. Baranov VS, Pendina AA, Kuznetsova TV, Efimova OA, Fedorova ID, Leont'eva OA, Korsak VS, Nikol'skiı̌ NN. [Peculiarities of metaphase chromosome methylation pattern in preimplantation human embryos]. [Article in Russian]. Tsitologiia. 2005; 47: 723-730.

46. Pendina AA, Efimova OA, Kaminskaia AN, Kuznetsova 
TV, Baranov VS. [Immunocytochemical analysis of human metaphase chromosome methylation status]. [Article in Russian]. Tsitologiia. 2005; 47: 731-737.

47. Pfarr W, Webersinke G, Paar C, Wechselberger C. Immunodetection of 5'-methylcytosine on Giemsa-stained chromosomes. Biotechniques. 2005; 38: 527-528, 530.

48. Inoue A, Zhang Y. Replication-dependent loss of 5-hydroxymethylcytosine in mouse preimplantation embryos. Science. 2011; 334: 194.

49. Kubiura M, Okano M, Kimura H, Kawamura F, Tada M. Chromosome-wide regulation of euchromatin-specific $5 \mathrm{mC}$ to $5 \mathrm{hmC}$ conversion in mouse ES cells and female human somatic cells. Chromosome Res. 2012; 20: 837-848.

50. Bogomazova AN, Lagarkova MA, Panova AV, Nekrasov ED, Kiselev SL. Reactivation of X chromosome upon reprogramming leads to changes in the replication pattern and 5hmC accumulation. Chromosoma. 2014; 123: 117128.

51. Efimova OA, Pendina AA, Tikhonov AV, Fedorova ID, Krapivin MI, Chiryaeva OG, Shilnikova EM, Bogdanova MA, Kogan IY, Kuznetzova TV, Gzgzyan AM, Ailamazyan EK, Baranov VS. Chromosome hydroxymethylation patterns in human zygotes and cleavage-stage embryos. Reproduction. 2015; 149: 223-233.

52. Dada R, Kumar M, Jesudasan R, Fernández JL, Gosálvez $\mathrm{J}$, Agarwal A. Epigenetics and its role in male infertility. J Assist Reprod Genet. 2012; 29: 213-223.

53. Laurentino S, Borgmann J, Gromoll J. On the origin of sperm epigenetic heterogeneity. Reproduction. 2016; 151: R71-8.

54. Ivanov M, Barragan I, Ingelman-Sundberg M. Epigenetic mechanisms of importance for drug treatment. Trends Pharmacol Sci. 2014; 35: 384-396.

55. Liang J, Yang F, Zhao L, Bi C, Cai B. Physiological and pathological implications of 5-hydroxymethylcytosine in diseases. Oncotarget. 2016; 7: 48813-48831. doi: 10.18632/ oncotarget.9281.

56. Kruger TF, Menkveld R, Stander FS, Lombard CJ, Van der Merwe JP, van Zyl JA, Smith K. Sperm morphologic features as a prognostic factor in in vitro fertilization. Fertil Steril. 1986; 46: 1118-1123.

57. Tolmacheva EN, Kashevarova AA, Skryabin NA, Lebedev IN. Epigenetic effects of trisomy 16 in human placenta. Mol Biol (Mosk). 2013; 47: 423-432.

58. Vasilyev SA, Tolmacheva EN, Kashevarova AA, Sazhenova EA, Lebedev IN. Methylation status of LINE1 retrotransposon in chromosomal mosaicism during early stages of human embryonic development. Mol Biol (Mosk). 2015; 49: 165-174.
59. Olszewska M, Barciszewska MZ, Fraczek M, Huleyuk N, Chernykh VB, Zastavna D, Barciszewski J, Kurpisz M. Global methylation status of sperm DNA in carriers of chromosome structural aberrations. Asian J Androl. 2017; 19: 117-124.

60. Kuznetzova T, Baranov A, Schwed N, Ivaschenko T, Malet P, Giollant M, Savitsky GA, Baranov V. Cytogenetic and molecular findings in patients with Turner's syndrome stigmata. J Med Genet. 1995; 32: 962-967.

61. Grigorian AS, Kruglyakov PV, Taminkina UA, Efimova OA, Pendina AA, Voskresenskaya AV, Kuznetsova TV, Polyntsev DG. Alterations of cytological and karyological profile of human mesenchymal stem cells during in vitro culturing. Bull Exp Biol Med. 2010; 150: 125-130.

62. World Health Organization. WHO laboratory manual for the Examination and processing of human semen (5th edn). WHO Press: Geneva, 2010; 271.

63. Pendina AA, Efimova OA, Chiryaeva OG, Tikhonov AV, Petrova LI, Dudkina VS, Sadik NA, Fedorova ID, Galembo IA, Kuznetzova TV, Gzgzyan AM, Baranov VS. A comparative cytogenetic study of miscarriages after IVF and natural conception in women aged under and over 35 years. J Assist Reprod Genet. 2014; 31: 149-155.

64. Pendina AA, Efimova OA, Fedorova ID, Leont'eva OA, Shilnikova EM, Lezhnina JG, Kuznetzova TV, Baranov VS. DNA methylation patterns of metaphase chromosomes in human preimplantation embryos. Cytogenet Genome Res. 2011; 132: 1-7.

65. Pendina AA, Efimova OA, Tikhonov AV, Chiryaeva OG, Fedorova ID, Koltsova AS, Krapivin MI, Parfenyev SE, Kuznetzova TV, Baranov VS. Immunofluorescent staining for cytosine modifications like 5-methylcytosine and its oxidative derivatives and FISH. P. 337-346. In "Fluorescence In Situ Hybridization (FISH)", Liehr T (Ed.), 2nd edition. Springer-Verlag Berlin Heidelberg, 2017, 606 P.

66. Negoescu A, Lorimier P, Labat-Moleur F, Drouet C, Robert C, Guillermet C, Brambilla C, Brambilla E. In situ apoptotic cell labeling by the TUNEL method: improvement and evaluation on cell preparations. J Histochem Cytochem. 1996; 44: 959-968. 